\title{
RECONCILIATION THROUGH RELATIONALITY IN INDIGENOUS LEGAL ORDERS
}

\begin{abstract}
ALAN HANNA $^{*}$
Canada's reconciliation with Indigenous peoples and groups in Canada is an ambitious goal with little in the way of clear direction. Canadian courts have provided limited direction in their decisions, yet the result of litigation has imposed a concept of reconciliation based on First Nations remaining subordinate to state authority and interests. Reconciliation will be confounded without gaining a shared understanding with Indigenous peoples. Different Indigenous groups will have their own interpretation of what reconciliation may require to be successful. One approach to seeking common understandings is for Canadians to learn how relationality operates as a function of disparate Indigenous legal orders. While substantive research into Indigenous legal orders is relatively new in Canadian scholarship, there is much knowledge to be gleaned from interdisciplinary research, particularly in anthropology, from the early twentieth century. At the risk of presenting an abrupt shift in disciplinary paradigms in this article, the author follows a thread of relationality from Canadian courts through the lens of doctrinal jurisprudence into relationality within various Indigenous legal orders through anthropological study. Combined, the article offers a potential path to reconciliation through relationality within Indigenous legal orders.
\end{abstract}

\section{TABLE OF CONTENTS}

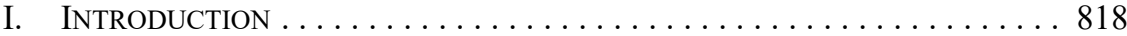

II. RECONCILIATION IN CANADIAN LAW . . . . . . . . . . . . . . 821

III. FiRST NATIONS - CANADIAN STATE RELATIONSHIPS

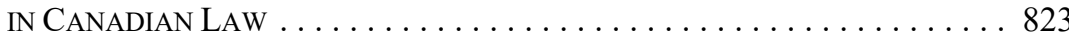

A. Defining Aboriginal Rights . . . . . . . . . . . . . . . . . 823

B. Duty to Consult . . . . . . . . . . . . . . . . . 825

IV. RELATIONALITY IN INDIGENOUS LEGAL ORDERS . . . . . . . . . . . . 828

V. RELATIONALITY THROUGH GitXSAN LAW . . . . . . . . . . . . . . . . . . . . . 829

VI. ANTHROPOLOGY AND INDIGENOUS LAW $\ldots \ldots \ldots \ldots \ldots \ldots \ldots \ldots$

A. ENFORCEMENT In DECENTRALIZED SOCIETIES $\ldots \ldots \ldots \ldots . \ldots 833$

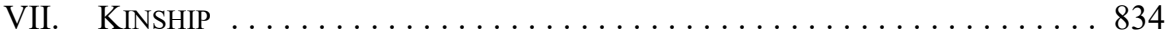

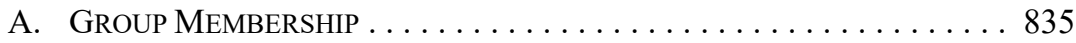

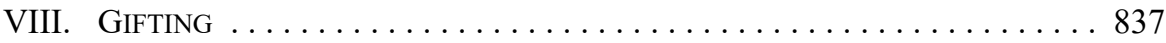

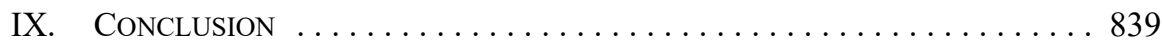

JD (University of Victoria), PhD Candidate in Law (University of Victoria). Alan teaches courses in Aboriginal law and Indigenous laws methodology at the University of Victoria. The author thanks his supervisors Val Napoleon, Michael Asch, and John Borrows for their support and insightful comments, and the Law Foundation of British Columbia and SSHRC for their generous support. 
This relationship between our Creator, our Mother, all other life forms, and ourselves forms the basis of all that we know to be true. This relationship forms the basis of our law. ${ }^{1}$

— Harold Johnson

\section{INTRODUCTION}

The latest efforts to improve First Nations-state relations in Canada is based on the notion of reconciliation. ${ }^{2}$ First Nations and Canada have engaged in relationship-building since early encounters with European arrivals on the lands we now collectively refer to as Canada. The early peace and friendship treaties in the east embody the essence of relational diversity through recognition and respect for the sovereign independence of the treaty parties. ${ }^{3}$ These treaties, and those to follow, are based on Indigenous legal traditions that govern relationality. ${ }^{4}$ The principle of linking arms together to provide strength in a relationship, and the Iroquois Gus-Wen-Tah, or Two Row Wampum, representing two separate paths of European and Indigenous peoples travelling the same river, symbolize this respect for independence. ${ }^{5}$ However, somewhere along the way, the tide turned and Canada (the beneficiary of these relationships) began asserting authority over Indigenous peoples and lands. This change was entrenched in law when British Parliament delegated legislative authority over "Indians, and Lands reserved for the Indians" to the Canadian government under section 91(24) of the Constitution Act, $1867 .{ }^{6}$

Around this time the relationships of First Nations and the Canadian state transformed from autonomous partners to paternalist subjugation. Canada sought to assimilate its Indigenous partners into the "body politic" of Canadian liberalism through several insidious laws and policies. ${ }^{7}$ As such, First Nations and Canada are seeking to emerge from more than

Harold Johnson, Two Families: Treaties and Government (Saskatoon: Purich, 2007) at 16.

A note on terminology: I use the terms Canada, the Crown, and state interchangeably, which includes its governments and citizens; I use the term First Nations to mean the present day political organizations of Indigenous nations and their communities (as they identify themselves) located within Canadian borders; the terms Indigenous peoples and groups are used to refer to non-Western societies including Métis and Inuit, and so-called "primitive" societies when referencing the terminology of early twentieth century anthropologists.

3 Robert A Williams Jr, Linking Arms Together: American Indian Treaty Visions of Law and Peace, 16001800 (New York: Routledge, 1999) at 4-5. See also Michael Asch, On Being Here to Stay: Treaties and Aboriginal Rights in Canada (Toronto: University of Toronto Press, 2014) at 116-18; John Borrows, "Wampum at Niagara: The Royal Proclamation, Canadian Legal History, and Self-Government" in Michael Asch, ed, Aboriginal and Treaty Rights in Canada: Essays on Law, Equity, and Respect for Difference (Vancouver: UBC Press, 1997) 155 at 163-64.

$4 \quad$ Williams Jr, ibid at 4, explains that through the Two Row Wampum, "the Iroquois were renewing a centuries-old indigenous North American legal tradition ... offering an American Indian vision of the law governing the relations between the different peoples of the world."

$5 \quad$ Ibid at $4,52-54$.

Constitution Act, 1867 (UK), 30 \& 31 Vict, c 3, reprinted in RSC 1985, Appendix II, No 5. Kent McNeil points out that "the source of the authority of the British Parliament to legislate for Canada has never been adequately explained," in "The Jurisdiction of Inherent Right Aboriginal Governments," Research Paper for the National Centre for First Nations Governance (11 October 2007) at 3, online: <fngovern ance.org/ncfng_research/kent_moneil.pdf>.

E Brian Titley, A Narrow Vision: Duncan Campbell Scott and the Administration of Indian Affairs in Canada (Vancouver: University of British Columbia Press, 1986) at 50. The identification of all of these are well-researched and will not be discussed here for the purpose of brevity. See generally Canada, Royal Commission on Aboriginal Peoples, Report of the Royal Commission on Aboriginal Peoples: Looking Forward, Looking Back, vol 1 (Ottawa: Communication Group, 1996); The Truth and Reconciliation Commission of Canada, Honouring the Truth, Reconciling for the Future: Summary of the Final Report of the Truth and Reconciliation Commission of Canada (Ottawa: TRC, 2015). 
a century of colonial violence and redefine their relationships through a process of reconciliation. This ambitious proposition raises questions, the answers to which people are now struggling to provide: (1) how is reconciliation defined; (2) by whom is reconciliation defined; and (3) how can reconciliation be achieved in a manner meaningful to Indigenous peoples and Canadians? This article sets out to grapple with these questions. The first two questions, how and by whom is reconciliation defined, can be summed up relatively quickly. Recognizing that within the geographic boundaries of Canada there are many discrete Indigenous groups, all with different specific historical relationships with the Crown, these groups likely have different meanings for the word "reconciliation." For example, Cree people do not have a direct translation for reconciliation. According to Cree speakers at the Reconciliation Wahkohtowin conference in Edmonton, Alberta in 2017, Wahkohtowin offers a Cree response to the English word "reconciliation," which means "the interconnectedness and interdependence of all things." ${ }^{8}$ Consequently, some Cree people may see reconciliation as meaning strengthening the relationships between the state, the people, the land, and the non-human relatives. For some Blackfoot people, reconciliation may be centred around sharing to "create and sustain 'good feelings." "For many Iroquois, reconciliation may mean returning to the original shared understanding of the peace and friendship treaties. For some Tsilhqot'in, it may mean establishing and maintaining balance between people and governments. ${ }^{10}$ And, for others, reconciliation may mean being able to walk down the street free of ugly stereotypes and racist attitudes. ${ }^{11}$ Canadians, on the other hand, tend to rely on interpretations of reconciliation established by courts and governments, as will be discussed in more detail below. Based on this brief discussion, going to each Indigenous community to settle on a proper definition of reconciliation responsive to the people would help establish a mutually nuanced version of reconciliation. Yet, how practical is this proposition considering the lengthy process of Royal Commissions ${ }^{12}$

This article engages more comprehensively with the third question by suggesting a path toward reconciliation on a nation-to-nation basis through the reconciliation of legal orders. A proposition of this scope is facilitated by understanding and making space for Indigenous legal institutions that regulate relationships. More specifically, I argue meaningful reconciliation is best achieved through relationality as a function of Indigenous legal orders, which requires Canada to learn how to be in respectful relationships with others on whose

Anna Desmarais, "U of A Conference a 'Turning Point' for Indigenous Law," CBC News (22 September 2017), online: <https://www.cbc.ca/news/canada/edmonton//university-of-alberta-reconciliationwahkohtowin-1.4301833>. See also Hadley Louise Friedland, "Wah-ko-to-win: Laws for a Society of Relationships" in Reclaiming the Language of Law: The Contemporary Articulation and Application of Cree Legal Principles in Canada (PhD Thesis, University of Alberta Faculty of Law, 2016) 151 at 164, 278 [unpublished].

$9 \quad$ Leroy Little Bear, "Jagged Worldviews Colliding" in Marie Battiste, ed, Reclaiming Indigenous Voice and Vision (Vancouver: UBC Press, 2000) 77 at 79.

Linda Ruth Smith, Súwh-tŝ'éghèdúdính: The Tsìnlhqút'ín Nímính Spiritual Path (MA Thesis, University of Victoria Department of Linguistics, 2008) [unpublished].

Carole Blackburn, "Producing Legitimacy: Reconciliation and the Negotiation of Aboriginal Rights in Canada" (2007) 13:3 J Royal Anthropological Institute (NS) 621 at 627.

The Truth and Reconciliation Commission of Canada (TRC) was operational for six years and held hearings across Canada to learn about inter alia what reconciliation means to Indigenous peoples affected by residential schools. The Calls to Action are definitive steps identified to help Canadians work toward a goal of reconciliation (The Truth and Reconciliation Commission of Canada, supra note 7 at 25). 
territories the state's society exists. A move towards this relationship on Canada's part involves commitment and engagement not only by government, but also by its citizens. ${ }^{13}$

This article begins by framing Canada's version of reconciliation as defined in the courts, and how courts shape relationships with First Nations as a product of litigation. This western phenomenon contrasts with Indigenous jurisprudence, which identifies relationships as the source of law itself causing people to create lawful obligations that maintain healthy relations. The difference in the distinction between these two assertions is that western law inscribes on the relationship the hierarchy required to maintain the unilateral authority of the Crown, whereas a relationship arising through an Indigenous legal institution provides entry into society that invites relationships with people and the land. To contrast Canadian courts' framing of reconciliation through its decisions, I offer one example of how the Canadian state may approach reconciliation by entering into a relationship with a First Nation (Gitxsan) in British Columbia through their legal order and the pathways available within its institutions such as kinship.

Following the contrast of court-made reconciliation with a reconciliation of Canadian and Indigenous legal orders, I provide a sketch of how law regulates relationality from within a few different Indigenous legal traditions. Anthropological research of the early twentieth century performed in places such as Southeast Asia and parts of Africa identified complex laws of so-called "primitive" non-western societies. Substantial research conducted during this early period of colonialism should not be overlooked, as it provides a rudimentary basis for understanding some general concepts in non-western social relationality that can be squared against what we are learning about Indigenous legal traditions in Canada today. Although the information provided is specific to non-western participants in the research, overarching concepts (or institutions) of kinship, group belonging, and gift exchange have a general application across a broad range of human societies.

The shift from western doctrinal law to laws articulated from the discipline of anthropology in this article may be uncomfortable for many lawyers and legal scholars. This discomfort is an effect of the compartmentalization of knowledge common within western academic institutions. Anthropology has a close relationship with law and legal practice as researchers and expert witnesses. Anthropology has also engaged in the study of law and legal systems for over a century, as this article shows. A present gap in legal knowledge (to which many lawyers will attest) is learning and understanding Indigenous legal orders in a manner that can be reflected in legislative drafting or presented as evidence in litigation. ${ }^{14}$

13 The TRC, ibid at 21, framed "reconciliation as relationship," stating [emphasis in original]:

Together, Canadians must do more than just talk about reconciliation; we must learn how to practise reconciliation in our everyday lives - within ourselves and our families, and in our communities, governments, places of worship, schools, and workplaces. To do so constructively, Canadians must remain committed to the ongoing work of establishing and maintaining respectful relationships.

14 One notable example is the evidence required to prove exclusivity on a territorial basis rather than being limited to sites of intensive use in the Tsilhqot'in title litigation, which required evidence of the existence of Tsilhqot' in laws. See generally Gary S Campo, "Do Aboriginal Laws Make a Difference: William v. British Columbia et al." (Paper delivered at the Canadian Bar Association, National Aboriginal Law Conference: Working With and Within Indigenous Legal Traditions, 11-12 April 2013) [unpublished]. 
One way to begin to address this gap is to turn to disciplines that have been studying Indigenous laws in connection with present scholarship. This article serves to offer a glimpse into this solution, which creates a paradigm shift when moving from doctrinal law in legal jurisprudence to doctrinal law in anthropological scholarship. However, from an interdisciplinary approach this article is about law, albeit from different lenses.

\section{RECONCILIATION IN CANADIAN LAW}

Although I only speculate above on what reconciliation may mean to some First Nations, there is a rich discussion on the subject within Canadian and international law. ${ }^{15}$ In the Supreme Court of Canada, Chief Justice Lamer held that the purpose of section 35 of the Constitution Act, 1982 is to reconcile Indigenous peoples' prior occupation of North America with the sovereignty of the Crown. ${ }^{16}$ Around the same time, the Royal Commission on Aboriginal Peoples (RCAP) also called for "reconciliation between Aboriginal and nonAboriginal people" in Canada. ${ }^{17}$ Although the United Nations Declaration on the Rights of Indigenous Peoples (UNDRIP) does not use the word "reconciliation," it promotes the concept. The UN General Assembly believes the recognition of Indigenous peoples' rights in the UNDRIP will promote "harmonious and cooperative relations between the State and indigenous peoples." 18 More recently, the Truth and Reconciliation Commission (TRC) defines reconciliation as being "about establishing and maintaining a mutually respectful relationship between Aboriginal and non-Aboriginal peoples in this country." 19 These references, in one way or another, endorse either the establishment of relationships (UNDRIP; TRC), or reconciling existing relationships (Supreme Court; RCAP). The TRC and UNDRIP offer clear objectives to facilitate respectful reconciliation through the Calls to Action and the Articles of the Declaration. Judges, exercising superior power to the TRC and UNDRIP through their capacity to bind parties, have made their own efforts at providing some direction for Canadian governments in seeking reconciliation.

15 I do not engage deeply with theories of reconciliation from the Western perspective here to ensure space for the focus on Indigenous legal relationality. However, I offer an overview of what has been discussed sufficient to set out some general concepts. See for example the section Justice Vickers drafted in his decision of the Tsilhqot'in title litigation, Tsilhqot'in Nation v British Columbia, 2007 BCSC 1700 at para 1338ff [Tsilhqot'in BCSC]. For discussions on reconciliation in international law see e.g. Joanna R Quinn, ed, Reconciliation(s): Transitional Justice in Postconflict Societies (Montreal: McGill-Queen's University Press, 2009); Paul Gready, The Era of Transitional Justice: The Aftermath of the Truth and Reconciliation Commission in South Africa and Beyond (New York: Routledge, 2011); John Paul Lederach, Building Peace: Sustainable Reconciliation in Divided Societies (Washington, DC: United States Institute of Peace, 1997) ch 3 at $23 \mathrm{ff}$.

$16 \quad R v$ Van der Peet, [1996] 2 SCR 507 at paras 31-32 [Van der Peet]. This purpose has been consistently affirmed in subsequent cases, for example Delgamuukw v British Columbia, [1997] 3 SCR 1010 at para 186 [Delgamuukw]; Haida Nation v British Columbia (Minister of Forests), 2004 SCC 73 at para 17 [Haida]. See generally Constitution Act, 1982, being Schedule B to the Canada Act 1982 (UK), 1982, c 11 .

17 See generally Canada, Royal Commission on Aboriginal Peoples, People to People, Nation to Nation: Highlights from the Report of the Royal Commission on Aboriginal Peoples (Ottawa: Supply and Services Canada, 1996), online: <www.aadnc-aandc.gc.ca/eng/1100100014597/1100100014637>.

18 United Nations Declaration on the Rights of Indigenous Peoples, GA Res 61/295, UNGAOR, 61st Sess, Sup No 53, UN Doc A/61/295 (2007) 1 at 3.

19 The Truth and Reconciliation Commission of Canada, supra note 7 at 6. 
The Supreme Court of Canada encourages the state to achieve reconciliation through a process of negotiation. ${ }^{20}$ Yet, as a starting point, negotiation is difficult considering the Crown's history of denying Aboriginal rights and title. ${ }^{21}$ Justice Vickers held that the doctrine of Aboriginal rights is the vehicle for achieving reconciliation, placing the court in the unenviable position of arbiter of the process. ${ }^{22}$ Justice Vickers cited Gordon Christie, who argued that for negotiations to occur on equitable terms, parties should accept Aboriginal rights as "sure and unavoidable" rights, which would give First Nations the bargaining power required to achieve a fair outcome, and "a resolution of the ills caused by centuries of colonialism." 23 This aligns with Brian Slattery's requirement for reconciliation to strike a balance between two objectives, "the need to remedy past injustices and the need to accommodate contemporary interests. $" 24$ The problem of seeking these objectives within Canada's current legal and political context is not difficult to identify — power imbalance.

Canada's liberal democracy, rooted in encouraging economic investment and development at almost any cost, is carried out at the expense of the so-called special or sui generis interests of Indigenous peoples and their relationships to the land. Canadian governments resist acknowledging broad Aboriginal rights, particularly rights that may include jurisdiction over land, for fear of interference with the continued development and extraction of resources. The tension that exists from competing claims for control over lands makes courts less than favourable forums for protecting the rights that will assist in achieving reconciliation. Chief Justice McLachlin expressed the Supreme Court of Canada's discomfort in being placed in the role of structuring reconciliation, as its power to "erode aboriginal rights seriously" appears intuitively at odds with the notion of guiding respectful reconciliation. ${ }^{25}$ Justice Vickers emphasized caution more directly, explaining that an adversarial system that must balance the interests of broader Canadian society is likely not best suited to achieving reconciliation, as happens when

the interests of the broader Canadian community, as opposed to the constitutionally entrenched rights of Aboriginal peoples, are to be foremost in the consideration of the Court. In that type of analysis, reconciliation does not focus on the historical injustices suffered by Aboriginal peoples. It is reconciliation on terms imposed by the needs of the colonizer. ${ }^{26}$

The unilateral determination of what constitutes reconciliation is sufficient to support a claim that the courts should not be relied upon to define or guide reconciliation.

Court-made tests reify Chief Justice McLachlin's and Justice Vickers' concerns by defining Aboriginal and treaty rights, including title, narrowly and discretely, parsed out of the interconnected societal complexity within which they were cast. Outside of rights litigation, reconciliation is defined through consultation and accommodation, a process that

Haida, supra note 16 at paras 20, 25.

Tsilhqot'in BCSC, supra note 15 at para 1136.

Ibid at paras 1166,1340 .

Gordon Christie, "Judicial Justification of Recent Developments in Aboriginal Law" (2002) 17:2 CJLS

41 at $69-70$, cited in Tsilhqot'in BCSC, ibid at para 1358.

Brian Slattery, "The Metamorphosis of Aboriginal Title" (2006) 85 Can Bar Rev 255 at 283, cited in Tsilhqot'in BCSC, ibid at para 1363.

Van der Peet, supra note 16 at para 313, cited in Tsilhqot'in BCSC, ibid at para 1349.

Tsilhqot'in BCSC, ibid at para 1350. 
continues to erode these narrowly defined Aboriginal and treaty rights under the courts' direction. Respectful reconciliation will not be achieved within this jurisdictional paradigm. It is more likely to be accomplished through a political interest in determining a shared understanding of how the parties should relate to one another, and what the intended outcome will achieve. As I argue, this can be accomplished through a relationship with Indigenous peoples, which requires some understanding of Indigenous worldviews and legal processes. The Supreme Court has held that reconciliation will require a balancing of both the Indigenous and western legal perspectives, but has had little success in backfilling that goal. ${ }^{27}$ Balancing these two ways of knowing the world leads to a discussion of how relationships are framed in both legal perspectives, beginning with an analysis of how Canadian courts shape the relationship between First Nations and the Canadian state.

\section{First Nations-Canadian State RELATIONSHiPS IN CANADiAN LAW}

\section{A. Defining Aboriginal Rights}

Canada has existing relationships with First Nations enshrined in the treaties from the earliest days of the colonial encounter, which are protected under section 35(1) of the Constitution Act, 1982. ${ }^{28}$ These include the peace and friendship treaties (mentioned above) and the numbered treaties, as well as modern comprehensive land claims and selfgovernment agreements. Conceivably, the Crown entered these treaty relationships, particularly the historic ones, with the expectation of creating enduring relationships with First Nations. ${ }^{29}$ Colonial negotiators invoked the language of kinship law that First Nations understood to enter into treaties. ${ }^{30}$ Despite the subsequent failure of Canadian governments to honour treaty promises, ${ }^{31}$ and the Supreme Court of Canada's framing of treaty rights in narrow terms as the remnants of Aboriginal rights, ${ }^{32}$ Indigenous treaty partners understood the treaties as containing duties and responsibilities established under their Indigenous legal

Van der Peet, supra note 16 at paras 49, 313.

Supra note 16.

For example, Treaty Commissioner Alexander Morris promised to Canada's treaty partners during negotiations of Treaty 6 , that the treaties would last "as long as the sun shines and the river runs," in The Hon Alexander Morris, The Treaties of Canada with the Indians of Manitoba and the North-west Territories, Including the Negotiations on Which They Were Based, and Other Information Relating Thereto (Toronto: Prospero Books, 2000) at 234-35.

30 For example, when negotiating Treaty 6 at Fort Carlton, Treaty Commissioner Alexander Morris said to the gathered crowd, "[m]y Indian brothers, Indians of the Plains, I have shaken hands with a few of you, I shake hands with all of you in my heart.... You are, like me and my friends who are with me, children of the Queen" (ibid at 199). Invoking kinship terminology invites a relationship according to the legal traditions of the Indigenous parties by utilizing legal mechanisms for entry into a group, as will be discussed later in this article.

31 Michael Asch argues that although the Crown negotiated treaties honourably, "we failed to fulfil our treaty promises" and that "there is not even a hint that we are obligated to fulfil our commitments once we have the power to ignore them" in Michael Asch, On Being Here to Stay: Treaties and Aboriginal Rights in Canada (Toronto: University of Toronto Press, 2014) at 154-55 [Asch, On Being Here to Stay].

32 The majority decision rendered by Justice Binnie in Mikisew Cree First Nation v Canada (Minister of Canadian Heritage), 2005 SCC 69 at para 31 [Mikisew] held that treaty rights are the residue of "surrendered and extinguished" treaty rights that are "expressly limited to lands not "required or taken up from time to time for settlement, mining, lumbering, trading or other purposes" [emphasis in original]. 
traditions. ${ }^{33}$ These duties and responsibilities are entrenched in Indigenous relationality, which will be discussed subsequently in this article. Suffice it to say that these kinship-based relationships, and the Canadian government's historical attempts to deny or diminish them, are shaped in the process of litigation as First Nations struggle to ensure their recognition and protection under section $35 .^{34}$

Indigenous people have rights under Canadian law intended to protect the interests and continued existence of Indigenous peoples; ${ }^{35}$ however, the Crown does not readily accept the existence and exercise of these rights. ${ }^{36}$ In Van der Peet, the Supreme Court crafted the test for proving Aboriginal rights. ${ }^{37}$ Although the Supreme Court ruled that, along with treaties, section 35 rights "must be given a generous and liberal interpretation," 38 these tests narrowly define the rights in a "partial and incomplete way." ${ }^{\text {"U }}$ Under the integral to distinctive culture test for proving an Aboriginal right as set out in Van der Peet, a claimant must marshal evidence to prove the claimed right existed at, or prior to, contact with Europeans (on a case by case, or right by right basis), that it has survived in some manner to the present, and is a "central and significant part of the society's distinctive culture."

A court will recognize only those rights that satisfy the test for Aboriginal rights under the common law. This test does not support broad claims, such as a broad claim to selfgovernment, although First Nations were self-governing prior to the arrival of Europeans. ${ }^{41}$ The test for Aboriginal rights restricts rights to individual practices that occurred in the past,

Williams Jr, supra note 3 at 71 wrote, "[w]hen we find Europeans referred to as brothers, colonial governors as fathers, or other tribes as cousins, uncles, or nephews in the treaty literature, we should recognize that, for Indians, each of these kinship terms had precisely understood meanings." For a thorough analysis of Indigenous relational obligations under Treaty 6, see Sharon Venne, "Understanding Treaty 6: An Indigenous Perspective" in Michael Asch, ed, Aboriginal and Treaty Rights in Canada: Essays on Law, Equity, and Respect for Difference (Vancouver: UBC Press, 1997) 173 at 184, 202-204; Johnson, supra note 1.

34 Although Aboriginal and Treaty rights are "recognized and affirmed" under section 35, the content and definition of Aboriginal and treaty rights are undefined, to be politically or legally determined. See Blackburn, supra note 11 at 624. See also John Borrows, Recovering Canada: The Resurgence of Indigenous Law (Toronto: University of Toronto Press, 2002) at 57 [Borrows, Recovering Canada]. Borrows, Recovering Canada, ibid at 75 explains that "Aboriginal peoples are entitled to expect legal protection for their continued existence as normative communities and nations within North America. Why entrench Aboriginal rights in the constitution if the societies they were meant to protect cannot survive?"

36 As the lengthy jurisprudence in Canadian case law stands testament. For example, historian Arthur Ray discussed his "astonishment" that a Crown prosecutor was about to argue against the claim that Cree hunters "had hunted and trapped for exchange purposes during the late 19th century," which Ray assumed was "common knowledge," in Arthur J Ray, "Ethnohistorical Geography and Aboriginal Rights Litigation in Canada: Memoir of an Expert Witness" (2011) 55:4 Can Geographer 397 at 397. I will forgo a discussion on title for the purpose of brevity; although I note that Aboriginal title has been referred to as a distinct subset of Aboriginal rights in Rv Adams, [1996] 3 SCR 101 at para 30. Test for Aboriginal Rights: Van der Peet, supra note 16; Test for Title: Delgamuukw, supra note 16, aff'd Tsilhqot'in Nation v British Columbia 2014 SCC 44 [Tsilhqot'in]. I agree with Borrows that the Tsilhqot'in title decision has provided a broader recognition of a right than other forms of Aboriginal rights (see John Borrows, "Challenging Historical Frameworks: Aboriginal Rights, the Trickster, and Originalism" (2017) 98:1 Can Historical Rev 114 at 129, 134 [Borrows, "Challenging Historical Frameworks"]), however, this right is still subject to justified infringement by the Crown (Tsilhqot'in, ibid at para 76). Aboriginal Rights: Defining the Just Society (Saskatoon: Native Law Centre, 2006) at 110. Borrows, Recovering Canada, supra note 34 at 76. See also Borrows, "Challenging Historical Frameworks," supra note 37 at 120 .

40 Van der Peet, supra note 16 at paras 55, 61-63.

$41 \quad R v$ Pamajewon, [1996] 2 SCR 821 at para 27. 
preventing the modern development of new rights that may emerge over time. ${ }^{42}$ Historic practices are subjected to the scrutiny of a legal system comprised of non-Indigenous judges who are expected to determine what was integral to the distinctive culture of an Indigenous people. ${ }^{43}$ James Youngblood Henderson argues that judges, being devoid of knowledge of the language and social, political, and legal systems that define a particular society makes their judicial analysis of what is integral to First Nations' culture absurd. ${ }^{44}$ Yet, this is the process for determining how First Nations' practices, including governance, are defined visà-vis the Crown. Rather than rights that are "sure and unavoidable," the courts' narrow definition of rights undermines the depth and complexity of First Nations societies, diminishing their position in nation-to-nation relationships with the unquestioned authority of the Crown. The effect is the subsuming of First Nations' interests to those of the Canadian public. ${ }^{45}$ The continued subjugation of First Nations' authority to the colonial authority of the Crown is evident in the constitutional protection offered under the Crown's duty to consult.

\section{B. Duty To Consult}

Leading up to the distinctive culture test, the Supreme Court of Canada in Sparrow introduced an infringement and justification test, which would serve to protect First Nations' interests in their ability to continue to exercise a claimed Aboriginal right. ${ }^{46}$ The infringement and justification test was subsequently applied to treaty rights in $R . v$. Badger ${ }^{47}$ In 2005 , the Supreme Court veered away from this approach of adjudicating the infringement of rights (proving them in the process) after the infringement occurred. Instead the Supreme Court imposed a duty to consult and possibly accommodate "when the Crown has knowledge, real or constructive, of the potential existence of the Aboriginal right or title and contemplates conduct that might adversely affect it." 48 The duty to consult was annunciated to protect unproven Aboriginal rights before possible infringement occurs, serving the interests of both First Nations and Canada. However, Canadian governments appear to gain the most from the consultation duty. The Supreme Court insists that First Nations do not have a veto, as the outcome of a consultation process is not guaranteed:

The s. 35 right to consultation and accommodation is a right to a process, not a right to a particular outcome: Haida Nation. While the goal of the process is reconciliation of the Aboriginal and state interest, in some cases this may not be possible. The process is one of "give and take", and outcomes are not guaranteed. ${ }^{49}$

This is despite Justice Lamer's holding that continuity and expression in modern forms attempts to prevent a "frozen rights" approach: Van der Peet, supra note 16 at para 64. See Borrows, "Challenging Historical Frameworks," supra note 37 at 116.

43 Borrows, Recovering Canada, supra note 34 at 59; Borrows, "Challenging Historical Frameworks," ibid at 116 ; Henderson, supra note 38 at 110.

$44 \quad$ Henderson, ibid at 206.

45 The Crown can infringe constitutionally protected Aboriginal rights if the infringement has a valid legislative objective and is in the public interest. The public interest has been expanded since its inception in $R v$ Sparrow, [1990] 1 SCR 1075 [Sparrow] through $R v$ Gladstone, [1996] 2 SCR 723 at paras 73-75; and Delgamuukw, supra note 16 at para 165, aff'd Tsilhqot'in, supra note 37 at para 83. Sparrow, ibid at paras 67-75.

[1996] 1 SCR 771 at para 82.

Haida, supra note 16 at para 35.

Ktunaxa Nation v British Columbia (Forests, Lands and Natural Resource Operations), 2017 SCC 54 at para 114 [Ktunaxa]; Haida, ibid at para 48. 
This seems a rather definitive statement that does not hold up under scrutiny. The Court has schooled the Crown in the ability to conduct meaningful consultation and accommodation through its litany of consultation decisions. ${ }^{50}$ Perfecting their engagement in the process, the Crown has learned that the standard of review for decisions to authorize projects will shift from correctness in the discharge of its duty to consult, to a standard of deference in a Minister's authorization of a project. ${ }^{51}$ The net effect is, contrary to the Supreme Court of Canada's ruling, consultation does guarantee an outcome if the Crown has properly discharged its duty, meaning governmental authorization of a project will be unassailable. ${ }^{52}$

The Supreme Court of Canada has demonstrated that if an affected First Nation is given "an informed and meaningful opportunity for dialogue" and "conditions of accommodation to adequately address the potential for negative impacts on the asserted rights" are imposed, ${ }^{53}$ an approval will stand. ${ }^{54}$ This appears to guarantee an outcome for the Crown. As there is no duty to reach an agreement, and First Nations do not have a veto even in projects that pose serious infringement, ${ }^{55}$ the Crown holds a disproportionate power over First Nations. The imbalance of power affirms Christie's concern that First Nations have little bargaining leverage when attempting to negotiate the preservation of their rights. The Court's assurance of the supremacy of Crown authority in this manner frames the relationship with First Nations as one of subjugation to that authority.

First Nations facing serious degradation of their rights due to environmental threats to their territories have few options in this relationship. ${ }^{56}$ Courts require First Nations'

See e.g. Taku River Tlingit First Nation v British Columbia (Project Assessment Director), 2004 SCC 74; Chippewas of the Thames First Nation v Enbridge Pipelines Inc, 2017 SCC 41 [Chippewas of the Thames]; Clyde River (Hamlet) v Petroleum Geo-Services Inc, 2017 SCC 40.

$51 \quad$ See e.g. Prophet River First Nation v British Columbia (Environment), 2017 BCCA 58 at paras 49-52, where the Court held that the judge applied the correct standard of review, reasonableness, in determining whether the Crown had discharged its duty to consult. See also Haida, supra note 16 at paras 61-63; Gitxaala Nation v Canada, 2016 FCA 187 at paras 182-83, where the Court held that "Canada is not to be held to a standard of perfection in fulfilling its duty to consult," only one of "reasonable satisfaction."

$52 \quad$ I am not aware of any court decision quashing a Minister's approval of a project for adverse effects of a First Nation's Aboriginal or treaty rights, when the duty to consult has been lawfully discharged. Chippewas of the Thames, supra note 50 at paras 2, 64 .

54 Courts have held that there may be occasions where the proper accommodation would be to refuse project approval, yet I am not aware of any example where the Crown has refused to approve a project on such a basis. See Blaney v British Columbia (The Minister of Agriculture Food \& Fisheries), 2005 BCSC 283 at para 127; West Moberly First Nations v British Columbia (Chief Inspector of Mines), 2011 BCCA 247 at para 149 for this principle. See also Ktunaxa, supra note 49 at para 83.

55 Haida, supra note 16 at paras $10,48$.

56 Significant and irreversible adverse effects from permanent losses through changes to the environment amounting to a serious infringement of treaty rights were on the consultation table in Adam v Canada (Environment), 2014 FC 1185 at para 11; Prophet River First Nation v British Columbia (Environment), 2015 BCSC 1682 at para 57. In these cases, consultation was held to be adequate to discharge the Crown's duty, therefore the approvals stand. The recent Federal Court decisions in Taseko Mines Limited v Canada (Environment), 2017 FC 1099; Taseko Mines Limited v Canada (Environment), 2017 FC 1100 [Taseko Mines] offer some hope for First Nations who are facing significant environmental impacts. The Federal decision-maker rejected the New Prosperity mine proposal on the recommendation from the Federal Review Panel, which identified that the mine posed significant adverse environmental effects. The Federal Court upheld the decision under judicial review, rejecting Taseko's request to have it quashed based on a number of issues, such as "allegations of breaches of procedural fairness and jurisdictional errors, as well as a constitutional challenge" (Taseko Mines, ibid at para 5). Whether the federal rejection of the project was based solely on the significant adverse environmental effects alone, or was strengthened by the adverse effects on the Tsilhqot'in people, is not clear; however, the Report includes both as reasons for recommending not to approve the project (see Environment Canada, Report of the Federal Review Panel: New Prosperity Gold-Copper Mine Project (Ottawa: Canadian Environmental Assessment Agency, 2013) at ix). How much influence Tsilhqot'in's proven Aboriginal rights and title had on the matter is also not clear. Justice Phelan held that " $[\mathrm{t}]$ his litigation concerns a 
participation in the erosion of their rights through the process of consultation. ${ }^{57}$ As a last resort, a First Nation may potentially litigate the infringement of Aboriginal or treaty rights subsequent to the consultation process. ${ }^{58}$ They may also litigate to prove title to prevent infringement. ${ }^{59}$ The manner in which First Nations are urged to participate in consultation and are expected to accept the Crown's decisions short of agreement, or be forced to litigate to protect their rights in a system that is ill equipped to grapple with the complexity and interconnected relationality regulated under First Nations legal orders, seems oppressive. Turning to the courts established by the same government that seeks to diminish the constitutionally protected rights First Nations are attempting to preserve shows a desperate (and absurd) situation within which we seek reconciliation. The adversarial system is costly and time consuming, producing a winner and loser. ${ }^{60}$ Surely this is not the meaning of reconciliation courts and governments envision as succeeding with the endorsement of First Nations.

The conundrum of reliance on the courts to shape the relationship that is expected to foster reconciliation becomes clearer in plain language. ${ }^{61}$ The courts' stated role is to ensure the Crown acts honourably. The Crown is expected to "balance societal and Aboriginal interests in making decisions that may affect Aboriginal claims," a responsibility requiring "[b]alance and compromise" in a process of "give and take." ${ }^{62}$ Proponents come to the table with money, investors, and a plan to develop land or extract resources from lands with which Indigenous peoples have maintained complex relationships since long before the Crown claimed sovereignty. In the process of accommodation, the Crown takes up traditional or treaty lands from Indigenous peoples without their consent, eroding Aboriginal and treaty rights in the process, to give to proponents for development. ${ }^{63}$ Clearly the Crown is taking land, but what is it giving in this process? The process appears to be a one-way street. ${ }^{64}$

How can Canadian governments, and the courts relied upon to oversee governmental exercises of power, exercise authority in a responsible manner without proper knowledge of the Indigenous legal orders that give meaning to and regulate relationships to the land and to other people? ${ }^{65}$ Indeed, Chief Justice McLachlin recognized the importance of reconciling

First Nation that has proven aboriginal rights and title to its land. The strength of those rights is an important context for the duty to consult" (Taseko Mines, ibid at para 92). Whether either of these decisions will be appealed is not known at the time of this writing. For a discussion on the two options the Crown imposes on First Nations (negotiate or litigate), see generally Alan Hanna, Crown-First Nations Relationships: A Comparative Analysis of the Tsawwassen Final Agreement and Tsilhqot'in v. British Columbia (MA Thesis, University of Victoria Faculty of Social Sciences, 2011) [unpublished]. Mikisew, supra note 32 at para 65, cited in Nlaka'pamux Nation Tribal Council v British Columbia (Environmental Assessment Office), 2011 BCCA 78 at para 79.

See Mikisew, ibid at para 48.

This was the Tsilhqot'in Nation's response to the issuing of timber permits without their consent. See generally Tsilhqot'in, supra note 37; Tsilhqot'in BCSC, supra note 15.

60 This is the result Justice Vickers cautioned against in Tsilhqot'in BCSC, ibid at para 1360.

61 Haida, supra note 16 ("consultation and accommodation ... preserves the Aboriginal interest pending claims resolution and fosters a relationship between the parties that makes possible negotiations, the preferred process for achieving ultimate reconciliation" at para 38).

62 Ibid at paras 45, 48-50; aff'd Ktunaxa, supra note 49 at para 80.

63 The majority in Ktunaxa, ibid at para 83 held that "[w]here adequate consultation has occurred, a development may proceed without the consent of an Indigenous group."

64 In contrast with the Court's "recognition that consultation is a two-way street," in Ryan v Fort St James Forest District (District Manager), [1994] BCJ No 2642 (QL) (SC), aff'd (1994), 40 BCAC 91, cited in Sonia Lawrence \& Patrick Macklem, "From Consultation to Reconciliation: Aboriginal Rights and the Crown's Duty to Consult" (2000) 79 Can Bar Rev 252 at 276. Henderson, supra note 38 at 110 . 
the dual perspectives, begging the question: how can this be achieved ${ }^{66}$ To assist Canada's commitment to reconciliation of its nation-to-nation relationships with First Nations, Canadians should consider a reconciliation of legal orders. This requires an understanding and engagement in more than just the colonial perspective. The short answer is that courts and governments should acquire information and training on Indigenous legal perspectives. After all, Indigenous peoples have been learning Canada's system for a long time.

\section{RELATIONALITY IN INDIGENOUS LEGAL ORDERS}

Generally speaking, relationality is experiential, expressed in the lived experiences of people and embodied in the person. ${ }^{67}$ This embodiment is further complicated by the interweaving of law with language, spiritual beliefs, relationships with the natural world, and ontology of a people. ${ }^{6}$ Anishinaabek scholar Aaron Mills explains this complexity as the "lifeworld of law" meaning "the set of ontological, cosmological, and epistemological understandings which situate us in creation and thus which allow us to orient ourselves in all our relationships in a good way." ${ }^{, 69}$ WSÁNEĆ scholar Robert Clifford explains that law and a person's worldview are inseparable. ${ }^{70}$ These relationships are complex, requiring a complex system of laws to manage them. Relationships are governed by various laws within long-held institutions, such as kinship to permit membership that imposes rights and obligations and gifting to maintain relationships. The obligations that arise within these Indigenous legal institutions regulate and maintain interactions with others (human and nonhuman) and the kinds of behaviour that people can expect and rely upon from others. As such, relationality within Indigenous worldviews is an important source of law, which adds a sixth category to John Borrows" "Five Sources of Indigenous Law."

Relationality itself creates the need for norms, rules, and practices in the form of expectations (what to expect of others) and obligations (responsibilities to others) that guide behaviour to ensure the proper maintenance of relationships. Proper maintenance of

Van der Peet, supra note 16 at 313.

I Schapera, A Handbook of Tswana Law and Custom, 2nd ed (London: Oxford University Press, 1955). Anthropologist Isaac Schapera understood this in the society he was studying in 1938 (Tswana), and explained it as follows at 36 :

The Tswana employ various mechanisms to ensure that all members of a tribe conform to its recognized norms of conduct [law]. Children are carefully taught by their parents the difference between right and wrong conduct. At the initiation ceremonies associated with the formation of age-regiments, more formal instruction of the same nature is given, certain definite rules of behaviour being firmly impressed upon the minds of the young people concerned. Later, as an adult, every man participates fully in the life of his tribe, and learns by actual experience what he may or should lawfully do and what is forbidden or resented. As husband, father, kinsman, subject, fellow tribesman, worker, and owner of property, he soon becomes aware, through his dealings with his family, neighbours, and political superiors, of the rights to which he is entitled and the duties he must fulfil.

RS Rattray, Ashanti Law and Constitution (London: Oxford University Press, 1969) at ix explains that religion is inseparable from law in the Ashanti world.

Aaron Mills, "The Lifeworlds of Law: On Revitalizing Indigenous Legal Orders Today" (2016) 61:4 McGill LJ 847 at 852.

Robert YELḰÁTTE Clifford, “WSÁNEĆ Legal Theory and the Fuel Spill at SELEK-TEL-(Goldstream River)” (2016) 61:4 McGill LJ 755 at 761-62.

They are sacred, natural, deliberative, positivistic, and customary in John Borrows, Canada's Indigenous Constitution (Toronto: University of Toronto Press, 2010) at 24-55 [Borrows, CIC]. Borrows does not omit relationality in his discussions of Indigenous ways of being. On the contrary, he often refers to relationality as entanglements. For example, Borrows explains " $\mathrm{t}] \mathrm{o}$ be alive is to be entangled in relationships not entirely of our own making. We are only a small part of a greater whole" in John Borrows, Law's Indigenous Ethics (Toronto: University of Toronto Press) [forthcoming in April 2019]. 
relationships means the continuation of them through the management and resolution of conflicts and tensions that potentially threaten a relationship. The following section offers an example of how Canada could potentially approach reconciliation with a First Nation through the Nation's Indigenous legal order in contrast to the relationship created through litigation in a western context.

\section{RELATIONALITY THROUGH GITXSAN LAW}

Various works on the Gitxsan legal order have been published over the years that assist in understanding how relationality operates on the ground. Two sources will provide the foundation for Gitxsan relationality: Valerie Napoleon's doctoral dissertation, which is an in-depth study of the Gitxsan legal order; and Richard Overstall's paper on property according Gitxsan law. ${ }^{72}$

The Gitxsan legal order is based on the institution of kinship, organized by clan relations into a wilp (House). ${ }^{73}$ The family lineage tracing back to its relationship with the land (its daxgyet) is the source of a family's authority. ${ }^{74}$ Families, or members of families, then authorize the House to exercise its authority externally. ${ }^{75}$ Therefore, the House carries the highest political and legal authority of the members of the House group. ${ }^{76}$ However, being a member of a kinship group carries roles and obligations, as it is "the people that create the legal relationships and accountabilities" on the territory. ${ }^{77}$ According to this structure, engagement with the legal order is through a kinship relationship.

Kinship relationships in the Gitxsan worldview are fluid and reciprocal, allowing people to move through the legal system based on their many relationships. ${ }^{78}$ There is more than one way to enter a kinship group. Descent within a family is obvious; however, a person may also gain legal status through marriage or adoption. ${ }^{79}$ Possessing jurisdiction and authority through their daxgyet, the ability to create additional mechanisms or legal fictions for kinship relations lies entirely with the Gitxsan people. Gitxsan may create other categories for membership, either temporary or permanent, as "kinship is a socially constructed way of looking at and relating to the world." ${ }^{\prime 0}$ Clearly, Gitxsan people do not live in a vacuum. There has always been interaction with other people from disparate legal orders in logical, reasoned processes. ${ }^{81}$ Arguably one of the more readily available categories for unrelated outsiders is as a niid'nt (guest) at a $y u k w$ (feast). ${ }^{82}$ The $y u k w$ is where Gitxsan jurisdiction is exercised and where legal decisions are made public. ${ }^{83}$ If invited, a niid'nt may attend a yukw

Valerie Ruth Napoleon, Ayook: Gitksan Legal Order, Law, and Legal Theory (PhD Dissertation, University of Victoria Faculty of Law, 2009) [unpublished]; Richard Overstall, "Encountering the Spirit in the Land: 'Property' in a Kinship-Based Legal Order"' in John McLaren, AR Buck \& Nancy E Wright, eds, Despotic Dominion: Property Rights in British Settler Societies (Vancouver: UBC Press, 2005) 22 at $22-49$.

Napoleon, ibid at 296, 301; Overstall, ibid at 31.

Napoleon, ibid at 6, 296-97; Overstall, ibid.

Napoleon, ibid at 297, 299; Overstall, ibid at 32.

Napoleon, ibid at 6.

Napoleon, ibid at 196, 301. See also Overstall, supra note 72 at 23.

Napoleon, ibid at 301, 320-21; Overstall, ibid at 44.

Overstall, ibid at 33-34.

Napoleon, supra note 72 at 297.

Napoleon, ibid at 301; Overstall, supra note 72 at 23.

Napoleon, ibid at xiii.

Napoleon, ibid at xv, 160; Overstall, supra note 72 at 35. 
and participate at a preliminary level in the legal order. Provincial and federal governments may consider engaging in an Indigenous legal order such as Gitxsan's if invited to do so. ${ }^{84}$ These invitations to participate are not merely suppositional.

In 2004, the federal government and the United Church participated in a yukw in Hazelton, where they apologized to Gitxsan people for the internment of children in the residential schools. ${ }^{85}$ Paulette Regan attended this event as a witness, and wrote about her experience as a way of honouring the gifts she received through the experience. Regan identified the yukw, and Canada's participation in a Gitxsan legal tradition, as a possible means for "making space for Indigenous legal traditions" through recognition and engagement with public ceremonies. ${ }^{86}$ Initial engagement in the Gitxsan legal order in the limited role of a guest is appropriate for state actors, as (although they will argue otherwise) "landless people are dependent on others and without power or status." ${ }^{\prime 87}$ The question from a relational perspective is whether Gitxsan people consider the Province of British Columbia as belonging to Gitxsan territory according to Gitxsan law, as having a daxgyet? The answer to this question could provide an opportunity for a nation-to-nation relationship between the Gitxsan and the Crown.

Although this is a matter for the Gitxsan people to broach, I suggest that the Crown has a kind of daxgyet, which could give Gitxsan people cause to create a designated "guest" House within the legal order for representatives of Canada ${ }^{88}$ Similar to Gitxsan families, the Crown's daxgyet is embodied and recounted in story. The Crown's is not the story of terra nullius, where Europeans arrived to find vacant, or politically vacant, lands to claim, own, and occupy as their own. The Supreme Court of Canada rejected this story in 2014. ${ }^{89}$ Canada's story is that when its settlers arrived from Europe, the Gitxsan were here, "organized in societies and occupying the land as their forefathers had done for centuries." Canada's story is one where a relationship is required from the outset to join the landscape of national multiplicity already here. As Overstall points out, within the Gitxsan legal order, "[i]mplicitly, a group without territory did not really exist in the world." ${ }^{.91}$ A designated guest House could provide Canadians with an opportunity to exist in Gitxsan law, and have representation within the Gitxsan legal order.

Mark Ebert discusses the possibility of convergence between the common law courts and the potlatch system, as an example of Canada engaging with Indigenous legal systems in, Mark Ebert, "Feasting Judicial Convergence: Reconciling Legal Perspectives Through the Potlatch Complex"' (2013) 18 Appeal 21.

Paulette Regan, “An Apology Feast in Hazelton: Indian Residential Schools, Reconciliation, and Making Space for Indigenous Legal Traditions" in Law Commission of Canada, ed, Indigenous Legal Traditions (Vancouver: UBC Press, 2007) 40 at 40.

Regan, ibid.

Overstall, supra note 72 at 37.

Gitxsan exercise a broad authority over the House system. They will split or merge Houses as the circumstances require. See Napoleon, supra note 72 at 208; Overstall, ibid at 32-33.

Tsilhqot'in, supra note 37 at para 69.

Calder v British Columbia (AG), [1973] SCR 313 at 328.

Overstall, supra note 72 at 37. 
Engaging in a relationship with the Gitxsan legal order based on respect and humility means entry will be on Gitxsan terms, by invitation, and state actors and citizens should come prepared to listen. ${ }^{92}$ And if Canadians are prepared, and are listening, they will hear the invitation. In a recent newspaper article on the Province's concern regarding informedconsent related to, primarily, liquified natural gas pipeline projects proposed to cross Gitxsan territory, one Gitxsan person stated:

If government or industry wanted to do any business on our territories, they should be doing the business in our feast halls. They have to remember they are visitors here. These agreements are happening because they know they need consent of the first peoples of these territories.... What's said in our feast hall is our law. ${ }^{93}$

This is an invitation to engage with the Gitxsan legal order. Each First Nation will have their own invitation with their own means of engaging with their legal order. Invitation to enter a relationship with people and land through Indigenous legal traditions, however beneficial, may be initially disconcerting for state actors who have a deeply entrenched worldview of land and resources as property. ${ }^{94}$ The commodification of land and animals driving massive resource extraction projects does not align well with the legal obligations that accompany Indigenous relationality toward peoples' natural relations to the land. Yet, these two concepts are commensurable when Canadian governments recognize First Nations authority over their lands, seek respectful relationships, and accept an appropriate role in a relationship through the First Nation's Indigenous legal order. ${ }^{95}$

From this suggestion for reconciliation based on relationality within a particular Indigenous legal tradition, I now turn to a few operative examples of how relationality works as a function of different legal traditions studied early in the last century.

\section{ANTHRopology AND INDigENOUS LAW}

Anthropology has a tenuous relationship with Canadian courts. The courts rely on anthropologists as experts to provide evidence on a range of topics related to a particular Indigenous group who is a party to litigation. This evidence may include aspects of the culture (norms, values, and beliefs), traditional practices, language, and the structure of the group's social organization. Anthropological experts are expected to have conducted in-depth study into the group and be impartial, objective observers and reporters. The objectiveness of early anthropology came under scrutiny in the early 1970s, and critique of anthropologists

92 Jeremy Webber, "Legal Pluralism and Human Agency" (2006) 44:1 Osgoode Hall LJ 167 at 197.

93 Trevor Jang, "Who Owns the Land - The People or the Chief?" (9 February 2017), the Discourse (blog), online: <https://www.thediscourse.ca/reconciliation/who-owns-the-land-the-people-or-thechief>.

94 Bradley Bryan offers a comparative analysis on "ways of owning and possessing" according to English conceptions of property and Indigenous understandings on relating to the world, in "Property as Ontology: On Aboriginal and English Understandings of Ownership" (2000) 13:1 Can JL \& Jur 3 at 3. An initial step toward this type of relationship may be the inclusion of input from First Nations, drawing on their Indigenous legal traditions, to inform legislation on a given subject matter such as hunting, fishing, logging, or mining. Drawing upon multiple legal orders to regulate these activities that occur on First Nations' lands would be an appropriate start toward a mutually respectful nation-to-nation relationship that includes Indigenous legal traditions. 
as experts in Aboriginal law litigation exists to the present. ${ }^{96}$ Accepting that objective, the ability of impartial anthropologists to sit on either side of litigation is problematic, bringing the objectivity of anthropology into question, I believe there is important and helpful knowledge from this scholarship that should not be overlooked or diminished because of valid critiques.

Different schools of anthropology focused on various aspects of Indigenous societies around the world in the twentieth century. For example, the school of British Social Anthropology (BSA) was concerned with the comparative study of social foundations of cultural development (in other words, patterns in societies and social behaviour), ${ }^{97}$ which set the BSA apart from the field of ethnography, whose focus was on the historical reconstruction of specific societies or geographic regions. ${ }^{98}$ Scholars of the BSA sought, understood, and recorded non-western legal systems. This early work of the BSA provides a depth of analytical support for contemporary Indigenous legal scholarship, as it shows how relationships are legally structured within various societies among kin and communities in relation to the land in these non-western systems.

There is a wealth of information in the old scholarly BSA books, but I will focus on a few examples of how the legal rights and obligations of different Indigenous groups operate in society and kinship as a means of illustration. This is not a comparative study, nor does it suggest there is a pan-Indigenous legal system, but rather offers a rough sketch, or survey, of a few of the findings in early anthropological research among different groups around the world.

Talal Asad, ed, Anthropology \& the Colonial Encounter (New York: Humanities Press, 1973) vilifies twentieth century social anthropology as being complicit in colonial oppression and advancing the interests of the British empire through its study of Indigenous peoples. Contemporary examples of the critique of anthropology in the courts include Dara Culhane, The Pleasure of the Crown: Anthropology, Law and First Nations (Burnaby: Talonbooks, 1998). See also Judge Gordon's commentary on the Crown's expert, cultural geographer Dr. Sheila Robinson, whose obstinance was disturbing, and whose evidence the judge found to be "ill-founded and mischievous" in Rv Billy and Johnny, 2006 BCPC 0048 at n 1. See Dara Culhane, "Adding Insult to Injury: Her Majesty’s Loyal Anthropologist” (1992) 95 BC Studies 66.

97 The BSA's search for patterns is relevant to litigation in the present, as lawyer for the Tsilhqot'in Nation, David Rosenberg, cross-examined Crown expert, Dr. Alexander von Gernet, on whether a pattern of protecting their land from outsiders meant that practice was entrenched as a practice that could help to prove exclusivity: "[y]ou'd [Dr von Gernet] agree with me that if you were asked to determine what actually happened in 1864, to reconstruct the past, you would want to look at the pattern, if you like, of the Tsilhqot'in people in that territory: did they protect their land before 1864 from incursion from outsiders, and did they continue to do so afterwards?" (Tsilhqot'in BCSC, supra note 15 (David Rosenberg cross-examination of Alexander von Gernet) Court Transcript, 7 September 2006, vol 126 at 21968 [emphasis added]).

98 AR Radcliffe-Brown, "Historical Note on British Social Anthropology" (1952) 54:2 American Anthropologist 275 at 275 . The historical inquiry into the origins of Indigenous societies and cultural practices embraced by the North American school is what gets taken up by Canadian courts in its efforts to define Aboriginal rights in the 1990s. In cases such as Van der Peet, supra note 16, the Supreme Court was interested in the social evolution of the Sto:lo society to decide whether they had reached a level of organized society that could possess a commercial fishery (ibid at paras 84,87 ). This is a basis for the argument in Borrows, "Challenging Historical Frameworks," supra note 37. Rather than defining Aboriginal practices as "cultural," located within a search for historical origins, the British school would have provided courts with a definition of Aboriginal practices as being interconnected within a contextual and complex legal structure that is deeply embedded in Indigenous societies. How might this have changed the Van der Peet decision? 
One of the BSA's foremost anthropologists, A.R. Radcliffe-Brown, recognized law in non-western societies as a mechanism for ordering structural relationships within a group, as he explained in the 1930s:

Any human social life requires the establishment of a social structure consisting of a net-work of relations between individuals and groups of individuals. These relations all involve certain rights and duties which need to be defined in such a way that conflicts of rights can be resolved without destroying the structure. It is this need that is met by the establishment of systems of justice and legal institutions. ${ }^{99}$

Radcliffe-Brown was not only acknowledging that a system of laws was being used to order relationships, he also explained that these laws were more than the whimsical initiatives of members of the group created to establish expected behaviour among members:

\footnotetext{
The social relationships ... are not haphazard conjunctions of individuals, but are determined by the social process, and any relationship is one in which the conduct of persons in their interactions with each other is controlled by norms, rules or patterns. So that in any relationship within a social structure a person knows that he is expected to behave according to these norms and is justified in expecting that other persons should do the same. ${ }^{100}$
}

The laws regulating relationships and behaviour were not mere randomly made rules, but were deeply contemplated social processes that were worked out, and re-worked over time (that is, law as a dynamic process). This allows people in decentralized societies to order their societies according to deliberate laws and processes. The normative behaviour, rules, patterns, and processes produce acceptable and predictable behaviour, offering one reason for abiding by rules without the threat of enforcement from a central authority. ${ }^{101}$

\section{A. ENFORCEMENT IN DECENTRALIZED SOCIETIES}

Researchers of Indigenous legal orders were (and often are) interested in discovering what compels people to abide by their laws when there is no recognizable formal legal system with central government, judges, and police to enact, adjudicate, and enforce a society's laws. ${ }^{102}$ Bronislaw Malinowski discovered that despite an individual's personal, self-serving interests, they will abide by laws simply for the benefit of being in relation to others. ${ }^{103}$

AR Radcliffe-Brown, "Patrilineal and Matrilineal Succession” (1935) 20 Iowa L Rev 286 at 298.

AR Radcliffe-Brown, Structure and Function in Primitive Society (Glencoe: The Free Press, 1952) at 10.

Bronislaw Malinowski referred to the adherence of obligations as the "mysterious propensity" to fulfil obligations without centralized enforcement authorities or, in many cases, without risk of punitive consequences (at least as members of western societies would understand them) (Bronislaw Malinowski, Crime \& Custom in Savage Society (New York: Harcourt, Brace \& Company, 1926) at 14).

See ibid at 9, 14. For a theoretical approach to the maintenance of horizontal obligations see Jutta Brunnée \& Stephen J Toope, "Interactional International Law: An Introduction" (2011) 3:2 Intl Theory 307. For a sense of how obligations are binding within the Cree legal order, see Darcy Lindberg, kihcitwâw kîkway meskocipayiwin (Sacred Changes): Transforming Gendered Protocols in Cree Ceremonies Through Cree Law (LLM Thesis, University of Victoria Faculty of Law, 2017) at 1-23 [unpublished].

Malinowski, ibid (" $[\mathrm{t}]$ he fundamental function of law is to curb certain natural propensities, to hem in and control human instincts and to impose a non-spontaneous, compulsory behaviour-in other words, to ensure a type of co-operation which is based on mutual concessions and sacrifices for a common end" at 64). 
People recognize the advantages of working together, foregoing self-interests and personal inclinations, to gain the mutual benefits that come from being in relation to one another through group belonging (safety, collective subsistence gathering, and socialization). Threat of reprisal or sanction from an enforcing authority is not necessary to ensure people abide by laws. Instead, there is a "binding machinery" that acts as a form of law enforcement, which is comprised of "reciprocity, systematic incidence, publicity and ambition."104 Reciprocity maintains ongoing obligations to be in relationships with others in a systematic way through the legal structure and the cooperative creation of rules. Publicity addresses legitimacy and compliance within the group, and ambition serves compliance by keeping everyone in the group working to achieve not only common goals, but also their own selfinterests within the group dynamic.

The personal interest to be part of a social group, rather than alone and isolated, supersedes a personal interest in doing whatever one pleases, which, arguably, would not keep them in the group (and perhaps even alive) for long. The principle to draw from this work is that a reason to abide by a legal order is not necessarily tied to fear of sanction (which does not prevent people from committing crimes in western society); rather it is an interest in being in relationships that enforces compliance.

\section{KINSHIP}

Kinship offers a system for organizing relationships according to legal rules provided by membership to a group through descent or other means. The status of belonging to a family, a community, and a nation involves a complex structure for organizing relationships on a legal basis. The structure contains nuanced law-making of relationality in non-western societies. $^{105}$

Kinship binds a society by creating obligations to those with whom a person is related, potentially ensuring promises are kept and responsibilities are upheld. As Michael Asch argues, people abide by the "rule-governed, reasonably coherent institutional setting within which to live and raise children in relative safety," as a means of ensuring safe and healthy relationships with others. ${ }^{106}$ These obligations then extend outwardly to govern relations with groups outside of a person's community through marriage rules enabled in the kinship institution. Asch argues that communities comprised of linked kinfolk are communities "within which promises are kept," and that members of multiple families (one's own, and the other(s) with whom they are in relation) "share a responsibility to sustain them both."107 Understanding the source of these obligations will help articulate the body of law that governs them.

Malinowski, ibid at 68.

Claude Lévi-Strauss, The Elementary Structures of Kinship, Rodney Needham, ed, translated by James Harle Bell, John Richard von Sturmer \& Rodney Needham (Boston: Beacon Press, 1969) at 490 asked: What is this world, unless it is that to which social life ceaselessly bends itself in a never wholly successful attempt to construct and reconstruct an approximate image of it, that world of reciprocity which the laws of kinship and marriage, in their own sphere of interest, laboriously derive from relationships which are otherwise condemned to remain either sterile or immoderate? In other words, what is life if we cannot find ways to perpetuate ourselves through our relationships with others?

Asch, On Being Here to Stay, supra note 31 at 128.

Ibid at $124-25$. 


\section{A. Group MeMberShiP}

Children are born into families and into the rights and obligations that come from either or both parents depending on the lineal descent structure of the society. ${ }^{108}$ Radcliffe-Brown explains the institution of kinship in general terms while recognizing the diversity of laws:

Everywhere in human society the status of an individual is very largely determined by birth, as the child of a particular father and particular mother. Behind the question of succession, therefore, lies the question of what elements of status, i. e. what rights and duties, are transmitted to the child by the father on the one hand and by the mother on the other. Every society has to establish its system of rules in this matter and there is an immense diversity of systems to be found in surviving and historic communities. ${ }^{109}$

Some societies are patrilineal, the bundle of rights and obligations flowing from the father's group, while others are matrilineal with legal status flowing from the mother's group, and in other societies, these rights may arise from the group itself. ${ }^{110}$ The rules of descent determining the rights and obligations of the person are often determined by complex processes that often vary depending on multiple factors including the gendered internal relations of the kin group. ${ }^{111}$ The rights and obligations flowing from descent may also vary.

Some rights involve hunting or gathering territories, gained through belonging to one's father's or mother's group or through marriage, which may include rights to the land itself or to the fruits of the land. ${ }^{112}$ Occasionally, depending on the society, obligations require married couples to take up humble and respectful residence with their in-laws and work hard assisting the in-laws in their labours. ${ }^{113}$ Although birth into a kinship group is one way of becoming part of the group, marriage being another, both of which will provide certain rights and responsibilities, they are not the only means.

Anthropologist Robert Rattray dedicates several chapters to the family and the rights and obligations passed down through descent (supra note 68 at 2-4). Raymond Firth, We, The Tikopia: A Sociological Study of Kinship in Primitive Polynesia (London: Routledge, 1936) at 371 explains belonging as:

The concept of descent means the membership of a kinship group by birth in a socially regulated manner. Membership of a group is constituted by the formal legal recognition that a person is an integral part of it, that he is entitled to share in the specific activities which are the aim of the group association, in such privileges as the bearing of the group name, and in such obligations as the regulation of conduct by the group limits and in its interests.

Radcliffe-Brown, "Patrilineal and Matrilineal Succession," supra note 99 at 292. Radcliffe-Brown's recognition of diversity within general concepts that apply across legal orders rejects the notion of panIndigenous law. This aligns with Leroy Little Bear's explanation that "there is enough similarity among North American Indian philosophies to apply the concepts generally, even though there may be individual differences or differing emphases" (supra note 9 at 77).

110 For an example of patrilineal descent, see Firth, supra note 108 at 361; for an example of matrilineal descent, see Rattray, supra note 68 at 8; and for rights of descent based on tribal affiliation, see Schapera, supra note 67 at 5.

111 For example, anthropologist Raymond Firth, ibid described the complexity he discovered working with the people of Tikopia in the South Pacific at 372 :

It is obvious that in any society the ties of bilateral kinship cut across the unilateral groupings on the basis of descent. The terminology of kinship stretches across from one clan or "house" to another, and so do other social ties. Thus in a "patrilineal" community such as Tikopia a man "belongs" to his father's group, is closely linked with his mother's brothers' group, co-operates with his wife's brothers' group, that is, his sister's son's group. Here the man is enmeshed in a web of which the strands are four independent patrilineal kinship units. A network of intertwined privileges, obligations and personal arrangements covers the whole community, fastening group to group through the individual ties of the members that comprise them.

Firth also mentions the stabilizing effects of a kinship system on society at 235 . 
Different societies have other ways of admitting people into the group. Some groups may require that a new member is at least from the same ethnic descent, but not always. For example, the laws of belonging for one group include the following:

(3) Clan descent alone confers the right (a) to inherit property; (b) to perform the sacra for ancestral spirits;

$(c)$ to succeed to certain offices; $(d)$ to be buried in a particular cemetery; $(e)$ to unite in the performance of certain funeral rights.

(4) The clan tie cannot be lost or broken save by expulsion from the clan.

(5) By a legal fiction, clan relationship might sometimes be acquired otherwise than by birth. ${ }^{114}$

Determining who belongs to a group is a fundamental aspect of autonomy and governance that applies generally in Indigenous societies. Membership by legal fiction is within the jurisdiction of the group to determine. This process was interrupted in Canada with the introduction of the Indian Act in 1876, when the federal government co-opted the decisionmaking process for determining who is an "Indian" and could belong to an "Indian band" based on ethnicity through descent. ${ }^{115}$ "Belonging" in Indigenous societies did not necessarily require strict adherence to the group's ethnicity. Indeed, kinship rules generally prohibited endogamous marriage in smaller societies (that is, marriages within the group and between groups). ${ }^{116}$ The following are a few examples of group membership where members are accepted from outside the group's ethnic lineage.

The first example is from the United States. According to Cheyenne law, the Council of Forty-Four (a council of tribal chiefs comprising Cheyenne government) generally required that one member was from outside the Cheyenne nation. ${ }^{17}$ This person was chosen for political reasons within the Cheyenne government. ${ }^{118}$ In another example from what is now British Columbia, before the smallpox epidemic ravaged the villages of the Secwepemc (Shuswap), people who lived along Tsilhqot'in (Chilcotin) territory, there was frequent intermarriage between the two nations. ${ }^{119}$ In 1909, ethnographer James Teit reported that the so-called Cañon group of Secwepemc peoples were "strongly mixed with Chilcotin, so much so that the people of the North Cañon band spoke chiefly Chilcotin in many houses." ${ }^{" 120}$ After smallpox took its grim toll, the few Secwepemc survivors relocated at Alkali Lake (Esketemc and Secwepemc) or Anaham (Tl'etinqox and Tsilhqot'in). ${ }^{121}$ This is an example of a social response to an unexpected and devastating epidemic. In my experience listening to Tsilhqot'in Elders, a person is either Tsilhqot'in or they are not. The intermarriage between Secwepemc and Tsilhqot'in people, and relocation of people of mixed Secwepemc descent

Rattray, supra note 68 at 70 .

Indian Act, RSC 1985, c I-5.

This was the purpose for such elaborate kinship systems, to ensure biological admixture through healthy, appropriate relational exchanges with others. See generally Lévi-Strauss, supra note 105.

KN Llewellyn \& E Adamson Hoebel, The Cheyenne Way: Conflict and Case Law in Primitive Jurisprudence (Norman: University of Oklahoma Press, 1941) at 67, 76.

Ibid at 76. The authors suggest the outsider was included to the group "as a constitutional measure guaranteeing formal governmental representation" with the neighbouring Sioux.

James Alexander Teit, "Part VII - The Shuswap" in Franz Boas, ed, The Jesup North Pacific Expedition: Memoir of the American Museum of Natural History, vol 2 (Leiden: EJ Brill, 1909) at 469.

Ibid.

Ibid at $459, \mathrm{n} 2$. 
into a Tsilhqot'in community does not change that definition, as the displaced smallpox survivors ultimately became Tsilhqot'in or Secwepemc regardless of their descent. A third example is found in Saskatchewan, where the Cowessess First Nation membership is described as multicultural, with a constantly shifting composition over time that includes, minimally, people of Cree, Saulteaux, Assiniboine, Métis, and mixed Indigenous-European ancestry. ${ }^{122}$ The purpose of providing these examples is to show that group membership was, and is, socially constructed. ${ }^{123}$

The group itself determines membership through kinship's various processes including descent, marriage, adoption, and legal fiction. These processes of becoming part of a group are a few of the practices illuminated through the work of the BSA in the early twentieth century when anthropologists were identifying and trying to understand the law and legal processes of Indigenous societies around the world. This work reveals that certain fundamental principles exist to support the legal structures organizing and regulating relationality. In addition to group belonging through kinship, and the legal fictions within that institution as just described, gifting is another mechanism in non-western societies that serves to initiate and maintain relationships in perpetuity.

\section{GIFTING}

Outside of the BSA, other social science scholars were also looking to identify the mechanisms that regulate relationships within and between non-western societies. One such scholar, Marcel Mauss, wrote that gifting in many Indigenous societies creates obligations between parties. ${ }^{124}$ The purpose of the obligation is to establish a relationship based on reciprocity that can continue in perpetuity. According to Mauss, there is an obligation to give and an obligation to receive. ${ }^{125}$ The failure to give is similar to the refusal to receive. Giving a gift is an invitation to "friendship and intercourse," whereas the decision to refuse a gift may be tantamount to a "declaration of war." 126 The process of exchange creates obligations to reciprocate and to accept one's participation in the relationship. Gifts may be shared in many forms, such as artistic expressions, songs, dances, and feast celebrations, which Mauss calls a "system of total prestations." ${ }^{127}$ Or, a gift may be simply an item such as "armshells,

122 Robert Alexander Innes, Elder Brother and the Law of the People: Contemporary Kinship and Cowessess First Nation (Winnipeg: University of Manitoba Press, 2013) at 90-107, 144.

123 Napoleon, supra note 72 at 297.

124 Marcel Mauss, The Gift: Forms and Functions of Exchange in Archaic Societies, translated by Ian Cunnison (New York: WW Norton \& Company, 1967) at 10. When Mauss refers to the gift, le don, he is referring to something more than merely presents, le cadeau. He is also referring to the gifts or talents with which a person is born (Michael Asch has done the work on making this distinction, as no one else has picked this up on this distinction, personal communication, 9 March 2017).

125 Mauss, ibid at 11.

126 Ibid. I am reminded of Michael Asch's caution against refusing food in the Arctic from stories among Dene and Inuit where refusing food could lead to war (personal communication).

127 Mauss, ibid at 3. I am flagging the noted exchange of women and children as forming part of the total system of prestations as deserving of a fulsome analysis and critique that goes beyond the scope of this article. This is an example of gendered violence and power differentials within Indigenous communities that is addressed in works of scholars such as Emily Snyder, Val Napoleon, and John Borrows in, for example, "Gender and Violence: Drawing on Indigenous Legal Resources" (2015) 48:2 UBC L Rev 593. See also Emily Jane Snyder, Representations of Women in Cree Legal Educational Materials: An Indigenous Feminist Legal Theoretical Analysis (PhD Thesis, University of Alberta Department of Sociology, 2014) [unpublished]; Lindberg, supra note 102. 
and necklaces" given at the kula in Mauss' description of one form of Polynesian exchange. $^{128}$

The obligations created through the exchange are due to the spirit of the gift wanting to return in one form or another (that is, not necessarily the same form it was given) back to the original giver. ${ }^{129}$ The spirit of the gift does not encourage opportunistic engagement for economic gain, as what eventually returns to the originating gift-giver should be equal to, or of higher value, than the original gift (yet the increase in value is not necessary). ${ }^{130}$ I suggest the obligation created through the exchange is the value in the giving of a gift, which does the relational work, as opposed to the value of the gift itself, reflecting a principle of generosity. ${ }^{131}$ I offer a contemporary example of how this exchange works by sharing a personal experience.

Between completing a Master's degree in anthropology and heading into law school a few years back, I worked a limited term contract with the provincial government. Upon my completion of the contract, a colleague from the Haisla Nation gave me a small, handmade cedar container as a parting gift. She explained that the gift was to accompany me through the challenges of law school ahead, and was not meant to be kept indefinitely. She said the gift was given to her when she was approaching a challenging time in her life, and that the purpose of the gift was to accompany a person through those times. The gift was not for me personally, but for me in company, in relation, for a time, after which I am to give the gift to the next person who is facing challenging times. I was told that I will know when this person comes along because the gift will be ready to go to them. That gift has bound me in relationship with not only my colleague, but with the creator of the gift (the original giftgiver), and the person to whom I will offer it. I have an obligation to continue this process because of my acceptance to receive the gift and the relationship that it created with my colleague. I have not yet passed the gift along. It has not yet signalled to me that the next person has come along, although it has come to mind on occasion. I am also still in a period of challenge as I work through my dissertation on the implementation of Indigenous laws. The gift and its spirit are alive in me, and I know it is not something I own as property; I am merely its caretaker for the time being.

Gifting and kinship are two Indigenous legal institutions, as they contain the laws and rules of behaviour for entry into, and maintenance of, relationships internal and external to non-western societies. The rough sketch offered here should provide some insight for legal scholars and practitioners into the internal workings of non-western legal orders as they apply to and regulate relationships. The insight stands in stark contrast to relationships formed in western legal arenas, such as courts.

See ibid at 17-18 on generosity. Although Mauss discusses three systems of exchange beginning with the circular exchange of gifts among the Trobriand Islanders, to the potlatch among the peoples along the Pacific northwest, to the western market system as a linear evolution in trading systems that present changes in the temporal aspects of each system, for the purposes of this article I am only interested in the legal obligations formed under such processes as a form of ordering relationships among people and groups. 


\section{Conclusion}

The Government of Canada claims it "is working to advance reconciliation and renew the relationship with Indigenous peoples, based on recognition of rights, respect, cooperation, and partnership." 132 Yet, in light of its continued infringement and erosion of constitutionally protected Aboriginal rights, reconciliation seems a laudable but unlikely goal. If Canada is to achieve nation-to-nation relationships with First Nations, politicians and citizens alike should attempt to meet the challenge that follows such an ambitious declaration. Reconciliation will not come easily. Nor is it likely to be achieved on the present path that maintains the status quo. If, as the Supreme Court of Canada has held, reconciliation is truly a two-way street, then Canada can and should be open to entering relationships based on Indigenous laws. ${ }^{133}$

Reconciliation by way of relationship requires a commitment to change, one that takes more than subtle tweaks and adjustments to an already broken, archaic system. ${ }^{134}$ First Nations have been open to teaching Canadians about Indigenous systems of law. Reconciliation with First Nations requires a sea change in the Canadian legal system and in peoples' minds to think and act in new ways that involve respect, reciprocity, humility, and equality. ${ }^{135}$ Engaging with Indigenous legal traditions after Indigenous people have been engaging with state law since the beginning of the colonial encounter is an act of reciprocity, which signals a sincere interest in recognizing difference and reconciling relationships. Indigenous legal institutions that regulate relationships, such as kinship and gifting, contrast with the Canadian courts' practices of constructing Aboriginal and treaty rights on narrow terms, thus facilitating a process of eroding those rights in the name of balancing interests for the benefit of industry. In this manner, judge-made law shapes relationships, in contrast to relationships shaping law in Indigenous relationality. The differences are as important as they are great. Learning how to reason and communicate across legal orders are equally as important if reconciliation is to be achieved substantively in Canada.

134 See Mariana Valverde's critique of Chief Justice Lamer's decision in Delgamuukw, supra note 16, in that he "writes as if the existing rules can be slightly modified to accommodate a wider variety of types of evidence," thus serving to "foreclose more radical challenges to the sovereign epistemological power" the Supreme Court of Canada possesses, in Mariana Valverde, "The Crown in a Multicultural Age: The Changing Epistemology of (Post)colonial Sovereignty" (2012) 21:1 Soc \& Leg Stud 3 at 12. 
[this page is intentionally blank] 